\title{
KREATIVITAS GURU PAUD DALAM PENCIPTAAN GERAK DAN LAGU TEMATIK UNTUK ANAK USIA DINI
}

\author{
Pance Mariati ${ }^{1}$, Sunanto ${ }^{2}$ \\ ${ }^{1}$ S1 Pendidikan Guru PAUD, Fakultas Keguruan dan Ilmu Pendidikan Universitas Nahdlatul Ulama Surabaya \\ ${ }^{2}$ S1 Pendidikan Guru PAUD, Fakultas Keguruan dan Ilmu Pendidikan Universitas Nahdlatul Ulama Surabaya \\ J1. Raya Jemursari No.57 Surabaya \\ pance_mariati@unusa.ac.id,alif30@unusa.a.cid
}

\begin{abstract}
The purpose of this study was to determine the creativity of the PAUD teachers in creating thematic movements and songs for early childhood which includes ideas, forms and processes of creating movements and songs. The research method used is descriptive qualitative with data collection techniques through observation, interviews and documentation. The results of this study contain descriptions of the creativity of the Teacher PAUD in the process of creating thematic movements and songs for early childhood, starting with the determination of ideas, the movement exploration stage, the motion improvisation stage and the movement formation stage. Where each stage of the creation of a motion and song is focused on a motion and a themed song according to the learning theme in PAUD. The conclusion of this study is, however, the form of motion and the song created by the Teacher PAUD should be adapted to the characteristics of the students. Good movements and songs are movements that are done by the children imitating the lyrics in the song. Because movements and songs can not only train physically, they can also train children's language.
\end{abstract}

Keywords: Creativity, PAUD Teacher; Creation; The motion of the song

Abstrak: Tujuan penelitian ini adalah untuk mengetahui kreativitas guru PAUD dalam penciptaan gerak dan lagu tematik untuk anak usia dini yang meliputi ide gagasan, bentuk dan proses penciptaan gerak dan lagu. Metode penelitian yang digunakan adalah deskriptif kualitatif dengan teknik pengumpulan data melalui observasi, wawancara dan dokumentasi. Hasil penelitian ini memuat deskripsi kreativitas Guru PAUD dalam proses penciptaan gerak dan lagu tematik untuk anak usia dini yang diawali dari penentuan ide gagasan, tahap eksplorasi gerakan, tahap improvisasi gerak dan tahap pembentukan gerakan. Dimana masing-masing tahapan penciptaan gerak dan lagu difokuskan pada gerak dan lagu bertema sesuai dengan tema pembelajaran yang ada di PAUD. Kesimpulan penelitian ini yaitu, bagaimanapun bentuk gerak dan lagu yang diciptakan oleh Guru PAUD hendaknya disesuaikan dengan karakteristik dari peserta didik. Gerak dan lagu yang bagus, adalah gerak yang dilakukan dengan anak-anak menirukan syair yang ada dalam lagu tersebut. Karena gerak dan lagu selain dapat melatih fisiknya, juga dapat melatih Bahasa anak.

Kata kunci: Kreativitas, Guru PAUD; Penciptaan; Gerak lagu

\section{PENDAHULUAN}

Dalam proses pembelajaran, tugas seorang guru tidak hanya mentransferkan ilmu kepada peserta didik, melainkan juga harus mampu membimbing dan memotivasi agar lebih aktif dalam proses pembelajaran. Tugas seorang guru yakni mampu untuk merencanakan kegiatan belajar mengajar secara efektif, seperti merumuskan tujuan pembelajaran, menentukan bahan atau materi pembelajaran, memilih strategi atau metode, serta menerapkan evaluasi pembelajaran dan sebagainya (Ahmadi, 2002:106). 
Peran seorang guru seharusnya mampu menyeimbangkan kinerja antara otak kanan dan otak kiri anak secara selaras. Sehingga akan menghasilkan kemampuan dasar yang sinergis dan akan menjadikan hasil belajar anak lebih optimal. Artinya bahwa, kreativitas anak akan berkembang jika ada proses keseimbangan antara belahan otak anak. Adanya kreativitas tersebut akan memunculkan analitis serta kemampuan yang luar biasa dalam berimajinasi kreatif. Sementara berimajinasi kreatif ini terdapat pada kegiatan-kegiatan seni (Handayaningrum, 2016: 2).

Menurut Semiawan (2009: 44) kreativitas adalah modifikasi sesuatu yang sudah ada menjadi konsep baru. Artinya yakni terdapat dua konsep lama yang digabungkan menjadi suatu konsep baru. Sedangkan menurut Utami Munandar (2009: 12), mengemukakan bahwa kreativitas adalah hasil interaksi antara individu dan lingkungannya, kemampuan untuk membuat bentuk yang baru berdasarkan data, informasi, dan unsur yang sudah ada atau dikenal sebelumnya. Semua pengalaman dan pengetahuan yang telah diperoleh seseorang selama hidupnya baik itu di keluarga, lingkungan sekolah maupun lingkungan masyarakat.

Kreativitas seseorang harus dikembangkan sejak dini agar kelak anak tumbuh menjadi orang yang percaya diri dan berkarakter. Pengembangan kreativitas anak selain dilakukan di rumah atau dalam keluarga juga dapat dikembangkan di sekolah. Pengembangan kreativitas anak selama di sekolah menjadi tanggung jawab dari pendidik atau guru sekolah. Kreativitas anak akan dapat berkembang jika guru juga memiliki kreativitas dalam pembelajaran. Guru harus mampu menciptakan inovasi-inovasi terbaru dalam pembelajaran guna meningkatkan kemampuan berfikir peserta didiknya. Kreativitas yang diciptakan oleh guru dalam pembelajaran akan memberikan dampak positif bagi pemahaman siswa terhadap pembelajaran yang diberikan. Setiap guru harus memiliki kreativitas dalam pembelajaran tidak terkecuali guru PAUD.

Menurut Fauzzidin, Komponen pokok kreativitas terdiri dari aktivitas berfikir, menemukan atau menciptakan, bersifat baru atau orisinil, serta berguna atau bernilai. Yang dimaksud dengan aktifitas berpikir, yaitu proses mental yang hanya dapat dirasakan oleh individu yang bersangkutan. Komponen kedua yaitu menemukan atau menciptakan, kegiatan ini bertujuan untuk menemukan sesuatu atau menciptakan hal-hal baru. Komponen ketiga yaitu baru atau orisinal, artinya bahwa suatu karya yang dihasilkan dari kreativitas harus mengandung komponen yang baru dalam satu atau beberapa hal. Komponen keempat yaitu berguna atau bernilai, karya yang dihasilkan dari kreativitas harus memiliki kegunaan atau manfaat tertentu (Fauziddin, 2016)

Salah satu kreativitas yang harus dimiliki oleh guru PAUD dalam pengembangan pembelajaran yakni dalam bidang seni. Pembelajaran seni merupakan salah satu pembelajaran yang menjadi kegemaran anak usia dini, seperti bernyanyi, menari, menggambar, menempel, menganyam dan sebagainya. Guru PAUD harus memiliki kemampuan seni yang bagus agar dapat mentransferkan ilmunya kepada peserta didiknya. Selain itu, guru PAUD juga harus kreatif dalam menyampaikan materi pembelajaran kepada anak didiknya. Salah satu kreativitas seni yang harus dimiliki oleh guru PAUD yakni dalam penciptaan gerak dan lagu untuk anak usia dini.

Dalam upaya mengembangkan kreativitas seni anak usia dini, Guru PAUD menciptakan Gerak dan Lagu Tematik atau Gerak dan Lagu yang sesuai dengan tema pembelajaran anak usia dini. Anak usia dini memiliki kecenderungan lebih mudah belajar apabila dilakukan dengan bergerak dan juga bernyanyi. Oleh karena itu, penulis 
tertarikuntuk membuat tulisan yang berjudul "Kreativitas Guru PAUD dalam Penciptaan Gerak dan Lagu Tematik untuk anak usia dini". Tujuan-penelitian ini adalah untuk mengetahui proses kreatif yang dilakukan oleh Guru PAUD dalam menciptakan gerak dan lagu tematik untuk anak usia dini yang meliputi, ide gagasan, bentuk gerak dan lagu, serta proses penciptaannya.

Penelitian ini sangat penting sekali dilakukan guna menambah referensi dalam bidang kesenian khususnya seni tari sederhana untuk anak usia dini. Mengingat semakin berkurangnya kesenian yang sesuai untuk anak usia dini dewasa ini. Harapannya, melalui penelitian ini dapat memberikan kontribusi ilmiah dalam bidan seni khususnya seni gerak dan lagu untuk anak usia dini

\section{METODE}

Metode yang digunakan dalam penelitian ini yakni metode penelitian deskriptif kualitatif. Metode penelitian kualitatif sebagaimana yang diungkapkan Bogdan dan Taylor (Moleong, 2007) yaitu sebagai prosedur penelitian yang menghasilkan data deskriptif berupa kata-kata tertulis atau lisan dari orang dan perilaku yang dapat diamati. Penelitian ini dilakukan dengan mendeskripsikan proses kreatif Guru PAUD dalam menciptakan gerak dan lagu tematik yang unik dan menarik bagi anak usia dini. Teori yang digunakan untuk membahas tentang proses kreatif penciptaan Gerak dan Lagu untuk anak usia dini ini mengacu pada pendapat Hawkins yang diterjemahkan oleh Sumandiyo Hadi.

Subjek penelitian adalah guru PAUD yang ada di beberapa daerah di kota Surabaya sebanyak 10 Guru PAUD. Teknik pengumpulan data yakni dengan menggunakan observasi, wawancara dan dokumentasi. Observasi dilakukan untuk mengetahui bentuk Gerak dan Lagu Tematik yang sesuai untuk anak usia dini, Wawancara dilakukan untuk mengetahui bagaimana langkah-langkah dalam penciptaan gerak dan lagu tematik untuk anak usia dini. Sedangkan dokumentasi yakni mendokumentasikan bentuk gerak dan lagu tematik yang diciptakan oleh Guru PAUD. Kegiatan analisis data yang dilakukan dalam penelitian ini yaitu mereduksi data, menyajikan data serta menarik serta menyimpulkan data-data tentang kreativitas Guru PAUD dalam penciptaan Gerak dan Lagu Tematik yang sesuai untuk anak usia dini.

Alur penelitian yang dilaksanakan diawali dengan studi pendahuluan yakni observasi awal pada Guru PAUD dan Studi Kepustakaan berdasarkan penelitian terdahulu. Tahap selanjutnya yaitu pelaksanaan penelitian yang dilakukan dengan mengidentifikasi jenis -jenis gerak dan lagu tematik dan proses penciptaan gerak dan lagu tematik. Setelah kegiatan penelitian, peneliti melakukan Teknik analisi data dengan cara mereduksi atau memilah-milah data mana yang digunakan dan data mana yang tidak digunakan. Langkah terakhir yaitu publikasi artikel di jurnal nasional terakreditasi.

\section{HASIL DAN PEMBAHASAN}

Gerak dan lagu merupakan salah satu kesenian yang sangat penting sekali diajarkan kepada anak usia dini. Selain dapat mengembangkan kreativitas dan rasa percaya diri anak, pembelajaran gerak dan lagu juga dapat melatih fisik anak. Hal ini sesuai dengan pendapat Widhianawati dalam Mariati (2017) yang menyampaikan bahwa pembelajaran gerak dan lagu yakni aktivitas bernyanyi yang dilakukan dengan gerak tubuh yang dapat mempengaruhi 
dan mengendalikan pusat syaraf. Gerak dan Lagu dapat membantu anak untuk lebih mengembangkan kecerdasannya tidak hanya pada aspek pengembangan Bahasa, kognitif, sosial dan emosionalnya saja tetapi juga pada pengembangan seni dan fisik anak (Mariati et al., 2017).

Mengingat pentingnya pembelajaran gerak dan lagu bagi anak usia dini, guru harus memiliki banyak referensi tentang materi gerak dan lagu yang akan diajarkan kepada peserta didiknya sesuai dengan tema pembelajaran. Permasalahannya adalah, tidak semua tema pembelajaran terdapat gerak dan lagu yang sesuai, sehingga guru dituntut untuk bisa menciptakan gerak dan lagu sesuai tema pembelajaran yang sedang berlangsung.

Berdasarkan hasil observasi dan wawancara kepada beberapa guru PAUD yang ada di Surabaya, dalam menciptakan gerak dan lagu sesuai dengan tema pembelajaran, langkah langkah yang perlu dilakukan yaitu memiliki ide gagasan, menentukan tema gerak dan lagu, melakukan proses penciptaan gerak dan lagu sehingga menghasilkan bentuk gerak dan lagu secara lengkap mulai dari gerakannya, musik iringan serta tata rias dan busana. Adapun langkah-langkah penciptaan gerak dan lagu tematik bagi anak usia dini yakni sebagai berikut:

\section{Ide Gagasan Penciptaan Gerak dan Lagu Anak Usia Dini}

Ide gagasan merupakan langkah awal yang harus dimiliki oleh seorang koreografer sebelum menciptakan karya tari atau gerak dan lagu tematik anak usia dini. Tahap ide, yaitu apa yang terjadi sampai dengan matangnya suatu ide (Mariati, 2016). Ide gagasan dalam penciptaan gerak dan lagu tematik biasanya mengacu pada kebutuhan dan ketersediaan gerak lagu tematik yang diperlukan anak usia dini. Misalnya seperti gerak dan lagu dengan tema rekreasi yang jarang ada contohnya baik dari youtube atau sumber yang lainnya. Sehingga, mau tidak mau guru termotivasi untuk menciptakan gerak dan lagu yang sesuai dengan tema pembelajaran rekreasi. Artinya bahwa ide gagasan yang muncul sebelum penciptaan gerak dan lagu yaitu menentukan tema dan judul gerak dan lagu yang akan dibuat.

Ide gagasan yang dimiliki oleh guru terbagi menjadi dua, yaitu ide gagasan murni atau ide gagasan yang muncul secara sendirinya dan ide gagasan yang muncul setelah mendapat motivasi dari sesuatu yang dilihatnya. Menurut Bunda Eny salah satu Guru PAUD di Surabaya menyampaikan bahwa ide gagasan dalam penciptaan Gerak dan Lagu yang dibuatnya bersumber dari gerak dan lagu yang dilihatnya dari youtube. Meskipun tidak memiliki kesamaan dalam penentuan tema dan bentuk gerak dan lagu, ide gagasan yang muncul dalam pikiran Eny sebelum menciptakan gerak dan lagu dipengaruhi oleh pengalaman seni yang dilihatnya dari youtube (Wawancara Eny, Juli 2020).

Berbeda dengan yang dialami oleh Bunda Iin dalam penciptaan gerak dan lagu dengan tema Rekreasi. Ide gagasan Bunda Iin sebelum menciptakan gerak dan lagu dengan tema rekreasi muncul secara alami atau tidak dipengaruhi dari aktivitas kesenian sebelumnya. Tujuan Bunda Iin menciptakan gerak dan lagu dengan tema rekreasi yakni karena adanya tuntutan untuk mengajarkan materi pembelajaran yang menarik sehingga muncullah ide untuk menciptakan gerak dan lagu dengan tema rekreasi, (Wawancara lin, Juli 2020).

Berdasarkan kedua pengalaman berkesenian kedua subjek penelitian tersebut, dapat disimpulkan bahwa ide gagasan dalam penciptaan gerak dan lagu tematik dapat muncul secara alami dan dapat juga muncul karena rangsangan aktivitas kesenian atau pengalaman kesenian sebelumnya. Hal ini senada dengan pendapat Smith dalam Mariati (2012:70) yang mengatakan bahwa Suatu rangsang diartikan sebagai suatu yang membangkitkan pikiran 
serta perasaan atau semangat yang mendorong kegiatan tertentu. Rangsang sendiri dibedakan menjadi dua yakni rangsang visual dan rangsang kinestetik. Rangsang vidual adalah rangsangan yang bersumber dari objek yang diamati baik objek bergerak maupun objek diam seperti objek berupa video, gambar, patung, pola, dan wujud. Sedangkan rangsang kinestetik yaitu rangsangan yang berasal dari gerak, baik gerak yang sudah pernah dilakukan maupun gerak yang belum pernah dilakukan

\section{Proses Penciptaan Gerak dan Lagu Anak Usia Dini}

Tahap kedua dalam penciptaan gerak dan lagu tematik yakni proses kreatif penciptaan gerak dan lagu tematik yang dilakukan oleh Guru PAUD. Proses penciptaan yang dilakukan oleh Guru PAUD mengacu pada pendapat Hawkins yang diterjemahkan oleh Sumandiyo Hadi. Menurut Hawkins dalam Mariati, Pengembangan kreatif dapat melalui tahap-tahap eksplorasi, improvisasi, serta komposisi (Mariati, 2016). Ketiga tahapan pada proses penciptaan karya gerak dan lagu tematik tersebut dipaparkan seperti di bawah ini.

\section{Tahap Eksplorasi}

Eksplorasi pada kegiatan kreatif yaitu kegiatan yang dilakukan dengan cara menyatukan objek seni serta memberikan si kreator perasaan baru tentang integrasi dan keutuhan Hawkins (1990:8) dalam (Mariati, 2016). Eksplorasi merupakan tahap awal dalam proses koreografi yang dilakukan sebelum improvisasi. Menurut Hadi, eksplorasi merupakan suatu tahap penjajagan terhadap objek atau fenomena yang terjadi dari luar dirinya, suatu pengalaman untuk mendapatkan rangsangan sehingga dapat memperkuat daya kreativitas. Tahap Eksplorasi mencakup kegiatan untuk memikirkan, mengimajinasikan, merenungkan, merasakan dan juga merespon objek-objek atau fenomena alam yang ada (Hadi, 1984).

Tahap Eksplorasi yang dilakukan oleh Guru PAUD dalam menciptakan Gerak dan Lagu Tematik yakni dengan cara mengamati bentuk gerak dan lagu tematik yang sudah ada sebelumnya. Baik dengan tema yang sama maupun tema yang berbeda dengan yang akan dibuat oleh Guru PAUD. Pengamatan video gerak dan lagu tersebut biasanya diperoleh dari youtube, lagu-lagu anak-anak, atau koleksi kaset tari anak lainnya. Melalui pengamatan yang dilakukan tersebut, Guru PAUD melakukan eksplorasi gerak dengan iringan lagu yang ditentukan sesuai tema. Adapun pada tahap eksplorasi ini yang dapat dilakukan yakni eksplorasi gerak, eksplorasi musik iringan, eksplorasi pola lantai dan ekplorasi rias busana.

Eksplorasi gerak yang diciptakan oleh Guru PAUD harus memperhatikan dari kemampuan gerak anak usia dini. Seperti gerakan sederhana yang lucu, unik, menarik dan sesuai dengan tema. Gerak tari untuk anak usia dini biasanya dilakukan searah, artinya bahwa antara gerak tangan, badan dan kaki dilakukan satu arah. Jika gerak tangan ke kanan, gerakan badan dan juga kaki dilakukan ke kanan. Jika gerakan kaki ke kiri, gerakan badan, tangan, dan kepala juga dilakukan ke kiri. Begitu juga dengan gerakan ke depan dan ke belakang yang dilakukan secara searah. Hal ini bertujuan agar anak usia dini tidak kebingungan ketika mengikuti gerakan yang diajarkan oleh guru. Selain itu juga mengajarkan konsep arah kepada anak usia dini. Gerak tari yang dibuat dalam gerak dan lagu tematik yang sesuai untuk anak usia dini ini biasanya tidak lebih dari lima variasi gerakan untuk memudahkan anak usia dini dalam mengingat gerak yang dilatihkan.

Eksplorasi musik merupakan pasangan yang tidak dapat dipisahkan dari eksplorasi gerak dalam penciptaan gerak dan lagu tematik. Eksplorasi musik juga harus memperhatikan karakter musik yang sesuai untuk anak usia dini. Karakteristik musik untuk anak usia dini 
yakni musik yang di dalamnya memuat struktur dan irama yang sederhana, tetapi relatif konstan. Hal ini merupakan jenis musik yang baik dan sesuai bagi anak-anak dalam periode ini. Struktur sederhana musik dapat dibentuk dengan susunan lagu dalam batas satu oktaf. Sedangkan irama musik yang baik yaitu berada pada rentang irama sedang, tidak terlalu cepat, dan juga tidak terlalu lambat (Utuh Priyanto, 2013).

Eksplorasi Pola lantai juga menjadi bagian terpenting dalam penciptaan gerak dan lagu tematik untuk anak usia dini. Pola lantai atau desain lantai adalah garis atau lintasan yang dilalui oleh penari atau bias juga diartikan sebagai pola di lantai yang dibuat oleh formasi penari kelompok (Jazuli 2008 : 18). Pola lantai yang sesuai untuk anak usia dini memiliki ciri yakni hanya terdiri dari 3-5 pola atau perpindahan. Tujuannya untuk memudahkan anak usia dini dalam mengingat gerakan sekaligus pola lantai ketika menari. Pentingnya pola lantai dalam gerak dan lagu tematik yaitu memberikan kesan yang menarik pada sebuah karya agar menarik dan tidak monoton.

Eksplorasi selanjutnya yaitu eksplorasi Tata Rias dan Busana. Tata rias yaitu sebuah aktivitas untuk mengubah penampilan seseorang dari wujud asli yang sebenarnya dengan bantuan bahan dan alat kosmetik menjadi bentuk yang berbeda dari aslinya. Tata rias memiliki dua jenis, yakni tata rias sehari-hari dan tata rias panggung. Tata rias panggung berbeda dengan tata rias untuk sehari-hari. Tata rias panggung lebih memperlihatkan kejelasan dari garis wajah dan juga ketebalannya. Tujuan dari penggunaan tata rias diharapkan dapat memperkuat dan memperjelas garis ekspresi wajah sehingga memberikan bentuk karakter. Fungsi tata rias sendiri yaitu mengubah karakter seseorang menjadi karakter tokoh yang sedang dibawakan untuk memperkuat ekspresi dan untuk menambah daya tarik penampilan (Jazuli 2008 : 23). Tata rias untuk gerak dan lagu anak usia dini harus menyesuaikan dengan tema gerak dan lagu yang dibawakan. Misalnya gerak dan lagu tema binatang kelinci, tata rias yang sesuai yaitu menyerupai binatang kelinci. Tata rias gerak dan lagu tema burung kutilang juga harus menyerupai burung kutilang, dan sebagainya.

Tata busana merupakan satu rangkaian dengan tata rias. Tata busana adalah pakaian dan semua kelengkapannya yang dipakai untuk menggambarkan tokoh. Fungsi busana tari yaitu untuk mendukung tema atau isi tari, serta untuk memperjelas peran dalam penyajian tari (Jazuli 2008 : 20). Tata busana yang digunakan dalam gerak dan lagu juga harus sesuai dengan tema yang dibawakan. Misalnya gerak dan lagu dengan tema binatang kelinci, maka busana yang digunakan juga menggambarkan binatang kelinci. Bisa dengan memakai pakaian berwarna putih-putih, memakai asesoris yang menyerupai telingga kelinci yang panjang dan sebagainya.

\section{Tahap Improvisasi}

Tahap improvisasi dalam penciptaan karya tari adalah salah satu tahap dari proses penciptaan tari selain eksplorasi dan komposisi. Ketiga tahap ini dilakukan untuk memperkuat kreativitas koreografer. Tahap improvisasi sering disebut juga dengan tahap mencoba-coba atau kegiatan yang dilakukan oleh seseorang secara spontanitas atau tiba-tiba. Karakteristik spontanitas menjadi tanda-tanda adanya proses improvisasi. Gerakan spontanitas dapat memberikan perbendaharaan serta memberikan variasi pengalaman gerak pada koreografer tanpa harus adanya perencanaan terlebih dahulu. Setiap koreografer maupun penari setidaknya harus memiliki banyak perbendaharaan gerak. Hal ini juga ditegaskan oleh Ellfeldt dalam (P. Mariati et al., 2016), bahwa setiap koreografer adalah 
seorang pencari gerak. Koreografer mengumpulkan bermacam-macam gerakan, kemudian dari gerak- gerak tersebut kemudian diseleksi untuk dipilih mana yang akan dipakai dan mana yang tidak kemudian dari gerak tersebut diolah dan disusun sesuai dengan konsep garap yang telah direncanakan.

Tahap Improvisasi yang dilakukan oleh Guru PAUD dalam penciptaan gerak dan lagu tematik yakni dengan mengumpulkan macam-macam gerakan yang sesuai dengan tema. Misalnya gerakan-gerakan burung kutilang untuk jenis gerak dan lagu dengan tema binatang. Gerakan binatang kelinci seperti melompat, makan, bermain untuk gerak dan lagu dengan tema binatang kelinci. Gerakan Pak Polisi yang tegap dan gagah perkasa untuk menggambarkan jenis gerak dan lagu dengan tema profesi, dan lain sebagainya.

\section{Tahap Komposisi atau Pembentukan}

Tahap Komposisi atau Pembentukan merupakan tahap yang terakhir dilakukan dari proses penciptaan tari. Setelah melakukan eksplorasi dan improvisasi, koreografer berusaha untuk membentuk atau mentransformasikan bentuk gerak menjadi sebuah tarian atau koreografi secara utuh. Pada tahap komposisi atau pembentukan ini juga termasuk menyeleksi atau mengevaluasi, menyusun, merangkai, atau menata motif-motif gerak menjadi satu kesatuan yang disebut koreografi. Menurut Hadi dalam Mariati, pada penyusunan motif- motif gerak menjadi sebuah koreografi, terkadang perlu adanya prinsip repetisi atau pengulangan (Mariati, 2016).

Bentuk gerak dan lagu tematik untuk anak usia dini sangat memungkinkan terdapat pengulangan-pengulangan gerak. Hal ini bertujuan agar anak lebih mudah dalam mengingat ragam gerak yang diajarkan. Salah satu prinsip yang sangat penting untuk diperhatikan bagi koreografer gerak dan lagu tematik untuk anak usia dini yaitu selain anak bergerak, anak juga harus mampu menyanyikan lagu yang digunakan untuk mengiringi gerak tersebut. Baik itu lagu yang menggunakan instrument ataupun hanya berupa syair saja.

\section{SIMPULAN DAN SARAN}

Berdasarkan pemaparan hasil penelitian tentang Kreativitas Guru PAUD dalam Penciptaan Gerak dan Lagu Tematik untuk Anak Usia Dini ini dapat disimpulkan bahwa, proses kreatif Guru PAUD dalam menciptakan gerak dan lagu tematik terdiri dari tahap penentuan ide gagasan baik itu muncul secara alami maupun non alami. Kemudian tahap eksplorasi yang meliputi eksplorasi gerak, musik, pola lantai, tata rias dan busana. Serta tahap Improvisasi dan tahap pembentukan gerak dan lagu. Guru PAUD harus kreatif dalam menentukan ide gagasan yang menarik dalam penciptaan gerak dan lagu, selain itu juga harus mampu menyusun gerak serta music yang sesuai untuk anak usia dini. Sehingga, gerak dan lagu yang diciptakan tepat pada sasaran dan bermanfaat untuk diterapkan dalam pembelajaran di PAUD.

Pentingnya pembelajaran gerak dan lagu untuk anak usia dini yaitu selain dapat meningkatkan kreativitas seni anak, juga melatih fisik serta Bahasa anak ketika anak bergerak sekaligus bernyanyi. Penciptaan gerak dan lagu tematik anak usia dini tidak perlu dibuat terlalu rumit dan susah, cukup dibuat sederhana saja. Yang terpenting adalah gerakan mampu ditirukan anak dan lagu mampu dinyanyikan oleh anak.

Kreativitas penciptaan gerak dan lagu tematik ini harapannya dimiliki oleh Semua Guru PAUD agar dapat memberikan pelajaran yang menarik bagi anak. Karena di dalam materi 
gerak dan lagu memuat bermacam-macam pelajaran yang dapat meningkatkan kemampuan anak baik kemampuan kognitif, sosial emosional, seni, fisik dan juga kemampuan Bahasa.

\section{DAFTAR RUJUKAN}

Fauziddin, M. (2016). Penerapan Belajar Melalui Bermain Dalam Meningkatkan Kreativitas Anak Usia Dini. Curricula, 1(3), 1-11. https://doi.org/10.22216/jcc.2016.v2i3.1277

Hadi, S. (1983). Pengantar Kreativitas Tari. Yogyakarta: Akademi Seni Tari Indonesia.

Hadi, S. 1984. Koreografi: Bentuk-Teknik-Isi. Yogyakarta: Akademi Seni Tari Indonesia.

Jazuli, M. 2008. Paradigma Kontestual Pendidikan Seni. Semarang: Unnes Universitas Press.

Mariati, P. \& Asmara, Berda (2017). Pengembangan Model Pembelajaran Inovatlf Gerak Dan Lagu Tematık Bagı Guru Pos Paud Terpadu ( Ppt) Dı Kota Surabaya. Universitas Nahdlatul Ulama. p. 3, 9-20. https://doi.org/10.30651/pegi.v3i3a.1028

Mariati, P., Nahdlatul, U., Surabaya, U., Markasa, A., \& Jombangan, T. N. (2016). Proses Kreatif Ali Markasa Dalam Penciptaan Tari. November, 1-7.

Moleong, L. j. (2007). Deskriptif Kualitatif. 71-74.

Utuh Priyanto. (2013). golden age. Jurnal Pendidikan Sendratasik, 2(082134244), 4252. $\quad$ https://jurnalmahasiswa.unesa.ac.id/index.php/jurnal-pendidikansendratasik/article/view/4648/6943 